\title{
Leaders and Political Culture: The Development of the Queensland Premiership, 1859-2009
}

\author{
Paul D. Williams
}

\section{Introduction}

The personal and political styles of leaders have long fascinated historians, biographers and political scientists eager to unravel the intricate nature of leadership and its impact on history. While some subscribe to the 'Great Man' theory that alleges that leaders' individual characters alone determine events, others believe in a 'materialist' conception where the prevailing socio-economic forces of the day shape history. ${ }^{1}$ The truth is probably a combination of the two. While leaders and events are primarily a function of environments, it will undoubtedly be leaders' individual characters that determine the finer details of history.

Democratic leadership holds special significance, given the variables leaders must negotiate to maintain coalitions of support among voters, with those leaders who deviate from the democratic 'norm' being of particular interest. This is especially germane to Queensland: a colony and later a state which, marking its sesquicentenary in 2009, has been both lauded and lampooned as somehow 'different'. ${ }^{2}$ And while every polity boasts uniqueness, it can be argued that Queensland varies from the Australian norm most dramatically in its 'political culture': in its institutions, its processes and the type of leaders the state produces. The study of Queensland political leadership - the focus of this article - thus reveals patterns that strongly suggest Queensland leaders have at once been shaped by the dominant political culture and, in turn - by their actions and as models for subsequent leaders - have shaped the ongoing development of that culture.

This article does not attempt a comprehensive history of the Queensland premiership, or provide biographies of the 36 men and one woman who have held that office on 45 separate occasions. It offers instead a broad overview in its three theses. First, it argues that the characteristics making for successful Queensland 
premierships did not originate with Joh Bjelke-Petersen in the 1960s, or even William Forgan Smith in the 1930s, as is often assumed in popular historical accounts. ${ }^{3}$ The article argues that the patterns of Queensland political culture were clearly identifiable from as early as 1860, under the first administration of Governor George Bowen and Premier Robert Herbert, with some elements even traceable to the inception of the Moreton Bay settlement in 1824. Second, the article argues that Queensland's political culture - anatomised here under five interrelated elements of 'strong leadership', 'pragmatism', 'regionalism', 'state development' and 'Queensland chauvinism' - has been exploited for electoral expedience, in varying measures and with varying success, by most premiers, with elements of that pattern still evident today. Third, it argues that intermittent modifications to Queensland's political institutions - and occasional developments in mass communications - have, over time, only enhanced the power and authority wielded by the Queensland premiership.

\section{Political Culture}

Colin Hughes defines political culture as

that part of culture which relates to the operation of a political system; it is the set of beliefs held by members of that culture about the way in which the political system and its actors behave, and the way in which they should behave, and is therefore both descriptive and normative. ${ }^{4}$

In summary, political culture is the way a community 'does' its politics - from the values it holds dear to its methods of conducting elections. It is, in short, a 'state of mind' that - like the 'populism' that forms a cornerstone of Queensland's political culture - can be reduced to 'the lowest common denominator of political belief'. ${ }^{5}$

Queensland's political culture derived its distinctiveness from a unique set of geographical, economic and social conditions. Even from its humble beginning in the $1820 \mathrm{~s}$ as a penal colony for the worst of New South Wales' recidivist convicts, Queensland was disposed to such authoritarian leaders as Commandant Patrick Logan who found the need to exercise disciplined, even brutal, colonial control. ${ }^{6}$ Even after the advent of free settlement (and, eventually, separation from New South Wales), Queensland's vastness and harsh terrain, its unforgivingly hot climate punctuated by drought and flood, its decentralised economy - and, with it, its sparse and decentralised population (with more residents living outside the capital of Brisbane than in it) - the need remained for tight governance. ${ }^{7}$ But Queensland's economy - disproportionately based on the primary industries of pastoralism, agriculture and mining - gave rise to other critical political and social phenomena, not least the under-development of secondary industries and, with them, a mercantile middle class that would otherwise have emerged as a natural liberal constituency more receptive to Westminster practices.

An over-reliance on primary industries also fostered 'country-mindedness': a heightened sense that farmers and rural dwellers were the backbone of both economy 
and society, with the rural classes feeling entitled to special privileges such as state aid, increased electoral representation and the like. ${ }^{8}$ Second, Queensland's ever-expanding horizon fostered a 'frontier' mentality where hard work by hard men could tame a cruel land and yield a glorious bounty. In this sense, Queensland was regarded in 'almost biblical' terms as a tabula rasa, or blank slate - a land which had to be cleared and developed, quickly and at all costs, lest the bounty be permanently lost to the elements or to foreign invaders. ${ }^{9}$ This frontier mentality and a pervading sense of isolation were manifested in a mistrust of central authority. Not only has Canberra been reviled as a den of centralist iniquity but, for regional Queenslanders, so too has Brisbane. It is not difficult to see the origins of such sentiments when one remembers that Brisbane is geographically closer to Melbourne than to Cairns. Such sobering realities had particular ramifications for development. Whereas rail lines - the classic metaphor for Queensland's industrial and social lifeblood - connecting western farms and mines to northern provincial ports were in place by the late 1800 s, no line connecting Brisbane to Cairns was opened until 1924. Clearly, Brisbane failed to dominate Queensland in the same way other state capitals did their states.

Queensland's obsession with development further encouraged a view that material progress in the shape of dams, bridges and roads was more highly valued than abstract liberal philosophies of public accountability. This in turn cultivated a political pragmatism - a flexibility among policy-makers that suggested virtually anything was permissible if it led to the successful and rapid development of the colony. Corners could be cut and due process bypassed if it meant the job was sure to be done. This saw generations of governments intervene heavily in economic affairs and spend lavishly on all sorts of infrastructure, with only schools languishing for want of substantial post-primary institutions. Lower levels of education in turn reinforced base political values, with masculine and illiberal attitudes, predisposed to authoritarianism, prevalent in rural and regional Queensland. These political values were often accompanied by sexist and racist undertones, where women and Indigenous people remained subjugated and patronised, with slow rates of nonEnglish speaking migration only serving to heighten suspicions of difference. This ultimately became evident in a fear and mistrust of outsiders, and even of locals who failed to fit the Queensland mould. Tolerance of dissidence was therefore low and treated with disdain, with a concomitant, almost blind obedience to law and order, and to religious and conservative values such as God, Crown and Flag, even among Labor leaders purportedly governing in the name of democratic socialism.

\section{Populism}

Many have described Queensland's political culture and leadership, at least in part, as 'populist, ${ }^{10}$ an amorphous term enjoying varied definition. Indeed, populism has been used to describe historical circumstances as diverse as the nineteenth century Russian Narodniks and the American Populist Party, the twentieth century Argentinean Juan Perón and Louisiana's notorious governor, Huey Long. ${ }^{11}$ But 
populism's complex historical composition can be defined by two broad themes that may, or may not, intersect: an emphasis on rural agrarianism and the mobilisation of the 'common people' against a vilified elite. Populist leaders - in representing a class perhaps dispossessed by technology or other social or economic change are often 'strong' and charismatic, speaking directly to the masses over the heads of other political actors and institutions. ${ }^{12}$

This article argues that Queensland's political culture is usefully defined as a unique form of populism, adapted to local conditions - an adaptation best understood in light of populism's appeal to the 'common people' and the lowest common denominator of public sentiment. ${ }^{13}$ This article further argues that Queensland's populist political culture consists of five core traits, expediently adopted, in part or in total, by most - but not all - premiers, with varying levels of success. These traits are discussed in turn below, with indicative examples offered as evidence.

\section{Strong Leadership}

The first, and perhaps most readily recognisable, trait of Queensland political culture is the 'strong' leader who, in his or her predilection for law and order and unilateral decision-making, has bordered on the authoritarian and the undemocratic. This tendency can be traced to the first days of the colony's separation from New South Wales in 1859, when the first Governor, George Bowen, ruled for some months as a 'true autocrat' with minimal advice from inaugural Premier and Colonial Secretary Robert Herbert (1859-66). It was a condition exacerbated by Queensland's status as the only Australian colony granted full responsible government at the time of separation - a fact that left the nascent colony with no ingrained practice and minimal political infrastructure. ${ }^{14}$ This administrative vacuum was filled quickly with centralised decision-making. Only later did Bowen share power with Herbert - yet, even then with parliament meeting infrequently, the executive's pre-eminent role in policy-making remained. ${ }^{15}$ The lack of an organised parliamentary opposition only enhanced Herbert's, and in turn Bowen's, power.

Charles Lilley (1868-70) emerged as another leader in the Bowen mould. While Lilley was progressive in political outlook, he was also 'a man of strong passions, iron determination and an indestructible belief in his own virtue'. ${ }^{16}$ It seems that, in Queensland, even liberals could be hard-headed - with Lilley, for example, failing to consult colleagues when undertaking the key education reforms of 1870 . Arthur Palmer (1870-74) earned a similar, if less attractive, reputation as 'the bully of the [Legislative] Assembly', with his enemies allegedly '[thinking] twice before crossing swords with him'. ${ }^{17}$ But Palmer also demonstrated strong leadership in delivering the first truly stable ministry, and in overseeing a flurry of legislative activity that saw 42 Bills passed in a single session. Thomas McIlwraith (1879-83; 1888 ; 1893) similarly launched into his three terms with such vigour that he was labelled 'the most headstrong and autocratic politician that Queensland has ever known'. ${ }^{18}$ Establishing his reputation by defeating John Douglas (1877-79) on the floor of the House, and enhancing it by taking on the Legislative Council, 
the conservative McIlwraith demonstrated a 'personal dynamism' that, like many subsequent leaders, saw him also become a 'good hater'. ${ }^{19}$

McIlwraith's successor and eventual nemesis, the liberal Samuel Griffith (1883-88; 1890-93), earned his own authoritarian stripes. Derided by opponents as a 'political dictator', Griffith was never seriously rivalled for his leadership. He also earned a reputation for being 'unwilling to delegate authority' - a trait other Queensland premiers later adopted. ${ }^{20}$ But the undemocratic tendencies in Queensland's political leadership reached an apotheosis of sorts when, in 1890, Griffith invited his rival McIlwraith to form a coalition colloquially labeled the 'Griffilwraith' arrangement, and later the 'Continuous Ministry', which endured until 1903. ${ }^{21}$ But it was not only this melding of liberal and conservative forces that strengthened the hand of successive premiers; the debilitating economic depression of the early 1890s also provided greater scope for Griffith and McIlwraith's personal intervention.

Labor historian Denis Murphy notes that William Kidston (1906-07; 1908-11), despite his social democratic politics, was often accused of 'despotism'. ${ }^{22}$ It seemed that, for Kidston, 'there was room for only one man on the sidewalk' ${ }^{23}$ The Liberal Digby Denham (1911-15) put his own stamp on Queensland in pioneering another trait that would become the hallmark of other authoritarian leaders: the beating of the 'law and order' drum. Denham's response to the industrial troubles of 1912, for example, was to confront the strikers head on. Under Labor's T.J. Ryan (1915-19), Queensland knew yet another strong, reformist premier. Assisted by being the first government with a clear parliamentary majority since the emergence of the modern party system - and by an efficient extra-parliamentary organisational wing - Ryan was 'always clearly the leader'. ${ }^{24}$ Indeed, it was Ryan's control over the Queensland Labor branch that prevented the local party splitting over conscription where other state Labor Parties were torn asunder. Ryan, of course, also exercised strong leadership when he confronted an intransigent and unelected conservative Legislative Council in the years leading up to that chamber's abolition in 1922: a development that enhanced the power of subsequent premiers beyond those of any interstate counterpart. Ryan's successor, Ted Theodore (1919-25), a man less concerned with ideology than with unvarnished power, was certainly a beneficiary. A 'born leader' who could also be 'autocratic', 'cold' and 'aloof', ${ }^{25}$ Theodore established a trade union at age 22 and, as premier, served for a time as his own treasurer to further consolidate his executive power. As an avowed anticommunist, the threats - real or imagined - posed by the Russian Revolution, and the radicalism of the International Workers of the World, bolstered the power of Theodore and others. ${ }^{26}$ By the time William McCormack (1925-29) assumed the premiership, a tradition of Labor autocracy was well established, one buttressed by Labor premiers' close personal relationship with the powerful Australian Workers' Union. In ruling party, cabinet and caucus with an iron hand, McCormack enforced an anti-communist pledge on to the ALP, consulted no one in assuming personal control of railways over the head of the Railways Commissioner, and refused to hold a Royal Commission into the collapse of the state-owned Chillagoe State Smelters. 
By 1927, McCormack had attained 'complete control' and, riding 'roughshod over opponents', was labelled 'tin pot Mussolini' by some. ${ }^{27}$

After a brief interregnum of conservative rule under Arthur 'Boy' Moore (1929-32), Labor's hegemony soon continued under the leviathan William Forgan Smith (1932-42). Perhaps even more power-hungry than McCormack, Forgan Smith won absolute control over party and government, and remained the unquestioned boss of the inner executive of Labor's Queensland Central Executive, a body that usually met in Forgan Smith's own parliamentary office. Indeed, the irreversibility of a Forgan Smith decision earned him the sobriquet of 'Foregone' Smith, ${ }^{28}$ a trait only enhanced by the Great Depression that, as in the previous depression under Griffith and McIlwraith, saw the premier assume increased powers of personal intervention. This decade saw also the proliferation of public communications. In 1933, a merger of the Brisbane Courier and The Daily Mail into The Courier-Mail saw the advent of a single, widely dispersed organ through which Forgan Smith and subsequent premiers could uniformly 'sell' their political message. Indeed, Forgan Smith was the first Queensland premier to employ public relations to any significant extent. An even more efficient medium, radio, had been introduced to Queensland in 1925, but it was not until 1932 that 4QG - the Queensland government's own radio station - became embedded in the $A B C$ 's wider network. ${ }^{29}$ In $1930,4 \mathrm{BC}$ and $4 \mathrm{BK}$ had begun operations, with $4 \mathrm{BH}$ commencing in 1932. A comparable expansion of regional stations soon followed. Like Theodore, Forgan Smith served as his own treasurer and, in suppressing dissidents, enacted the draconian State Transport Act 1938 that allowed him and subsequent premiers to flout civil liberties in the calling of 'states of emergency' that could not be overturned by the courts. Forgan Smith also politicised the public service to the point of 'clerical fascism', ordered police to spy on radicals, and personally intervened in the composition of the University of Queensland Senate. ${ }^{30}$ If nothing else, the sheer length of his tenure - at ten years, he was then the longest-serving premier - points to Forgan Smith's enormous control.

Ned Hanlon (1946-52) was perhaps even tougher on union unrest. Like Forgan Smith, Hanlon championed law and order in stymying striking meat workers in 1946, and railway workers in 1948. Hanlon also saw himself as a statesman when representing Queensland in negotiating trade deals with the British Commonwealth. Hanlon's disposition towards strong leadership is best captured in his own words: 'I'll never resign. They will have to carry me out with my boots on.' ${ }^{1}$ Hanlon did indeed die in office. Vince Gair (1952-57) completed the triumvirate of Labor autocrats, and was widely regarded as 'intolerant, arrogant and dictatorial'. ${ }^{32}$ His very coming to power proved an augury for opponents: on Hanlon's death, Governor Sir John Lavarack personally approached Gair to fill the vacant position, one Gair accepted without ever facing a caucus vote. The new premier soon became 'deliberately confrontationist', and was happy to introduce Bills without consulting Labor's Queensland Central Executive. ${ }^{33}$ Gair even legislated in 1953 to register all printing presses to limit underground dissidence and, in 1956, invoked his own state of emergency during the 1956 shearers' strike. ${ }^{34}$ It was undoubtedly Gair's 
pig-headedness that brought Labor's four decades of power to a close in 1957 when the party split over the issue of three weeks' annual leave for workers.

A new conservative hegemony of 32 years from 1957 meant nothing to Queensland's penchant for strong leadership. It is perhaps no surprise that new premier, Frank Nicklin (1957-68), soon fell into his predecessors' patterns, given that he had already led the opposition during sixteen wilderness years. Nicklin popularly known as 'Honest Frank' or 'Gentleman Frank' for his genteel public demeanour - in private used an iron fist to control wayward colleagues, a power reinforced from 1957 by two of his own reforms: his right to appoint his own ministry, and the establishment of an organised Cabinet Secretariat - the first such state apparatus in Australia. ${ }^{35}$ Nicklin, too, exploited law and order fears, most infamously during the 1961 Mt Isa Mines strikes when he authorised police through executive ordinance and not legislation - to enter any premises to prevent any 'undesirable' person from entering. ${ }^{36}$ Nicklin's accession also coincided with the proliferation of television that, like radio in the $1930 \mathrm{~s}$, allowed premiers to personalise their leadership within the family living room. QTQ 9, BTQ 7 and ABQ 2 each began broadcasting in Brisbane in 1959, with TVQ 0 commencing in 1965. Regional networks soon followed: by the mid-1960s, stations had been established in Toowoomba, Townsville, Wide Bay and Cairns. ${ }^{37}$ Nicklin's successor, Jack Pizzey (1968), died in office after only six months, but his attempts at strong leadership remain clear, especially in his own low regard for civil liberties and anti-Vietnam War protesters. ${ }^{38}$

Pizzey's early death led to the accession of a man synonymous with Queensland autocratic populism: Joh Bjelke-Petersen (1968-87). As Bjelke-Petersen's leadership is explored elsewhere in numerous lengthy studies, ${ }^{39}$ it is necessary to offer here only a few indicative examples. Indeed, Bjelke-Petersen's strong leadership like Forgan Smith's and Nicklin's - is encapsulated in his long tenure: a record nineteen-year Queensland record which is unlikely to be broken. Bjelke-Petersen quickly earned a reputation as a 'bearer of grudges', and as a leader who won election campaigns - assisted by his own brutal electoral malapportionment, which he inherited from the Hanlon government - on law and order fears and states of emergency declared during the 1971 South African Springboks' Rugby Union tour, and the 1985 SEQEB electricity strikes. ${ }^{40}$ With the tactical support of National Party president Robert Sparkes' organisational wing, and the pioneering public relations strategies of media director Allen Callaghan, Bjelke-Petersen controlled party, government and public opinion like no other premier had done. Indeed, Bjelke-Petersen once infamously remarked that 'you have to override people for their own good'. ${ }^{41}$ Media were managed, opposition was suppressed and civil liberties were ignored, with Bjelke-Petersen often hand-picking parliamentary candidates and public service and even police appointments. Bjelke-Petersen's zenith arrived in 1983 when he achieved a long-held dream: to govern in his own right without the Liberals - a feat he attained after refusing to recall parliament to test his minority government after the Coalition's dissolution. By this time, Bjelke-Petersen's control was complete, a development exploited in National Party campaign banners that, under an image of Bjelke-Petersen, displayed only 
two words: 'Joh - Queensland'. In the ultimate populist expression, The Leader had finally become inseparable from The State. It is perhaps not unexpected that Bjelke-Petersen's obsession with political control contributed to his own downfall in his ill-fated 1987 'Joh for PM' putsch.

The accession of Wayne Goss (1989-96) marked the beginning of what appears to be a second Labor hegemony. ${ }^{42}$ Interestingly, while Goss eschewed the base populism so often exploited in Queensland politics, the new premier accepted the mantle of strong leadership, with numerous references to 'Goss the Boss' and the 'Goss Gloss'. ${ }^{43}$ Indeed, in being a 'meticulous controller', Goss employed a 'Praetorian Guard' to support his centralised decision-making, particularly in the gatekeeping Cabinet Office headed by Kevin Rudd. ${ }^{44}$ And, while Goss's power - at least in theory - was mitigated by a post-Fitzgerald veneer of public accountability, he remained the 'arch controller' of cabinet and public service, with the reduction of departments from 27 to eighteen. ${ }^{45} \mathrm{He}$ also quelled decades of factional hostility. But, despite other key democratic reforms, parliament under Goss met no more frequently than under his predecessors. Ultimately, Goss's 'aloof' leadership contributed to Labor's unexpected electoral collapse in 1995.

Peter Beattie (1998-2007) invites obvious comparisons with Joh Bjelke-Petersen for his often-populist appeal, his long tenure and an almost total command of the political and policy agenda. Reinforced by a strong Premier's Department headed by such figures as Glyn Davis, Leo Keliher and Ross Rolfe, Beattie controlled cabinet and party alike, and frequently intervened in ministerial colleagues' portfolios such as Health and Indigenous Affairs. Beattie also took media management to new levels, with an army of 'spin doctors' vetting ministerial media releases. Like Goss, Beattie also enjoyed enormous authority over the party, with conference and factions readily falling into line. Beattie, too, banged the 'law and order' drum with 'anti-hooning' laws and police 'move on' powers and, as his own trade minister, happily assumed the 'face' of Queensland. But Beattie drew perhaps the most stinging parallels with Bjelke-Petersen in his 2007 legislation that forced 157 local government authorities to amalgamate into just 72 - a feat initially accompanied by threats of fines and dismissals should any council hold local plebiscites. ${ }^{46}$ Ultimately, Beattie's own sense of leadership came to light in the publication, while premier, of his own book, Making a Difference. ${ }^{47}$ The fact Beattie in 2007 chose the timing of his own departure (the first premier to do so since Nicklin), and groomed a successor, adds weight to the thesis that Beattie was a strong leader in the Queensland tradition. Anna Bligh (2007-present), by contrast, has attracted criticism for a leadership lacking in direction. ${ }^{48}$ But the rapidity with which Bligh sought to distinguish her premiership from Beattie's in, for example, the ordering of the Solomon Review of the state's Freedom of Information laws suggests Bligh at least possesses the potential for classically strong leadership. Indeed, it would be a potential amply demonstrated in Bligh's easy victory, despite opinion polls indicating a hung parliament, in the Queensland state election of 21 March 2009 an election she called six months ahead of schedule. ${ }^{49}$ Not only did Bligh deliver Labor a fifth term, she positioned herself as Australia's first female state premier 
elected in her own right. ${ }^{50}$ It was a remarkable development for an urban female leader in a state historically imbued with bucolic masculine values.

\section{Pragmatism}

Rae Wear defines pragmatism as 'a characteristic of Queensland political leaders' that evolved from 'the erosion of class-based ideology and its replacement by a commitment to state economic development as the principal measure of a government's success'. ${ }^{51}$ But pragmatic leadership in Queensland - where classbased ideology was regularly sublimated by the practical needs of administering a colony three times the size of France - can trace its origins back before the 1890 s and the rise of the party system. Pragmatism, then, can be defined much more broadly than economic concerns. It includes, first, an ideological flexibility that permits premiers to retract previously supported policies, and to shift support among political groupings to form new coalitions in the quest to maintain power. While especially critical in the years before disciplined political parties, this trait is still recognisable today in the form of 'vote catching' and the courting of powerful pressure groups. Second, pragmatism includes a populist rhetorical element which, in appealing to the common folk, exploits such sentiments as the virtues of the hard-working poor over the 'idle' rich, and of a sensible but under-educated class against an 'out-of-touch' intellectual elite. Third, pragmatism includes a propensity to ignore due process and instruments of public accountability, regarding them instead as annoying impediments to 'good' policy. For a state reliant upon a frontier economy where growth was the principal measure of success, pragmatism ultimately meant that, until the $1990 \mathrm{~s}$, 'parliamentary procedures were little understood'. ${ }^{52}$

From the first days after separation, Queensland politics fell into a pattern of pragmatism when Governor Bowen assumed a close working relationship that defied Westminster conventions. Instead of assuming the role of silent regal representative, Bowen instead took the lead, and at first excluded inaugural Premier Herbert from decision-making. But practicalities soon saw Bowen find the need to share power with the young Colonial Secretary in a duumvirate that largely circumvented parliament. ${ }^{53}$ Arthur Macalister (1866, 1867-68), Herbert's immediate successor, soon established his own patterns of pragmatism, and these would become a cornerstone of Queensland politics: the propensity to make and break alliances to suit one's own political ends - a tendency that earned Macalister the title of 'Slippery Mac'. ${ }^{4}$ Macalister was also subject to conflicts of interest in, for example, allocating land to a gas company of which he was a director. Indeed, land issues rapidly became the heart of political pragmatism. Macalister, for example, was his own lands minister as he pushed through land reform, while McIlwraith - in an infamous 'land scandal' - offered southern investors land at half the normal rate of 20 shillings per acre. ${ }^{55}$ McIlwraith faced his own conflicts of interest in, for example, his representation of pastoralism despite his enormous share in the same industry. These are but a few early examples of a deeply ingrained pattern of how Queensland was to be developed. Members would be 
elected, applications granted and favours extended on a 'back-scratching' basis of network 'connectional politics' that ensured 'survival through mutual dependency' among Queensland's rural communities. ${ }^{56}$ Griffith's pragmatism, of course, was overtly political - particularly in his invitation to McIlwraith in 1890 to form the 'Continuous Ministry'.

Hugh Nelson (1893-98) appeared to learn well the principles of pragmatism, knowing when to 'play' Griffith and McIlwraith against each other to his own advantage. Nelson was, in fact, 'a genius for getting down to first principles'. ${ }^{57}$ Robert Philp (1899-1903) also appeared pragmatic when, in establishing early patterns of 'cronyism', he appointed friends and supporters to key positions. Kidston's pragmatism, in turn, saw him vacillate between social democratic, liberal and conservative principles - a trait that saw him finally break with Labor in $1906 .{ }^{58}$ T.J. Ryan demonstrated his own electoral pragmatism in coalescing Labor and Liberal support, a formula that for decades would stand the ALP in good stead. Yet even Ryan's experimental 'state socialism' in such government-owned industries as insurance, butcher shops and hotels was also a popular, if ill-fated, pragmatic exercise - one sold to the electorate as a 'fair deal for everyone'. ${ }^{59}$ These distinctly populist overtones continued under Theodore, who made political capital out of anti-intellectualism, and who sought 'practical reforms' for farmers while also appealing to anti-imperial sentiments. ${ }^{60}$ And, while McCormack's pragmatism came in the closing of Ryan's unprofitable state enterprises, Moore's was found in calls for unity and an end to class warfare.

Forgan Smith's accession introduced a new phase of pragmatism in terms of his hatred of 'intellectual snobbery', and in his meddling in electoral infrastructure. Where Forgan Smith personally intervened in the 1935 redistribution, Hanlon would go further in 1942 and introduce - to split the non-Labor vote - 'first-past-the-post' voting. In 1949, Hanlon also drew up plainly undemocratic and malapportioned electoral boundaries. ${ }^{61}$ While Frank Cooper (1942-46) adopted his own populist pledge to put a refrigerator in every home, Gair exploited anti-intellectualism in his attacks on the University of Queensland, and 'anti-big business' sentiment in his attacks on oil companies.

Nicklin, like the early Labor premiers, adopted a pragmatic appeal that 'transcended political barriers', while at the same time deriding university radicals as 'egg-heads' and 'ratbags'. ${ }^{2} \mathrm{He}$ also continued the earlier 'pork-barrel' politics to the point of 'rural corporatist interventions' - for which he galvanised support in 1958 via his own zonal electoral system. ${ }^{63}$ Nicklin also introduced compulsory preferential voting in 1962, to end the split in conservative support. Pragmatism, like authoritarianism, reached new levels under Joh Bjelke-Petersen. Conflicts of interest soon emerged in 1970 over the Premier's Comalco Aluminium shareholdings, a controversy from which he emerged unscathed, surviving a party room challenge by his questionable use of a proxy vote. ${ }^{64}$ It was a pragmatism that plumbed new depths when Bjelke-Petersen broke convention in 1975 to appoint the politically sympathetic Albert Patrick Field - instead of Labor's nominee - to replace the deceased Labor Senator Bert Milliner. Bjelke-Petersen also honed his populism: in his abolition of death duties; in his condemnation of radical students, street 
marchers and trade unionists; and even in his personal communication with voters, where mangled syntax and mixed metaphors suggested a man of the common people. Indeed, the premier often spoke of his school of 'hard knocks' and his earlier 'cow bale' home, and made known his refusal to join the generous parliamentary superannuation scheme. Bjelke-Petersen also took cronyism and electoral malapportionment to new levels, and offered unprecedented media and public accessibility.

Goss redefined this pragmatism in his embrace of economic rationalism at the expense of old Labor shibboleths - an approach that enabled him to adopt the populist appeal of a financially prudent leader looking out for the best interests of families and the state. Goss's National Party successor, Rob Borbidge (1996-98), was equally pragmatic in successfully forging the first Coalition since 1992: a practical and solid arrangement with Liberal leader Joan Sheldon that delivered power for two years. Borbidge, too, fell into old habits in politicising the public service, and in drumming up rural fear in 1996 over Prime Minister John Howard's gun control laws and the High Court's Wik decision of the same year that empowered Indigenous Australians. ${ }^{65}$ Interestingly, these very issues - and commensurate anxieties over immigration, globalisation and economic rationalism - contributed to the rise of the unashamedly populist Pauline Hanson's One Nation, a party formed in 1997 which, by the following year, had captured eleven parliamentary seats and almost 23 per cent of the primary vote. ${ }^{66}$

Beattie's populist pragmatism, like Bjelke-Petersen's, was writ large in his plain speaking, in his identification with 'battlers', in his condemnation of oil companies and banks, and in his self-presentation as 'Everyman' - an amiable 'boofhead' who enjoyed pizza, football and walking his dog, Rusty. ${ }^{67}$ Indeed, Beattie, when caught out using immoderate language, defended the use of the 'great Australian adjective', and portrayed himself as a family man concerned about his children, his wife and his weight. Ultimately, Beattie recognised the pragmatism of avoiding the 'politician' tag. He took, for example, a fiscally prudent line in warning colleagues against accepting gratuities, and a hard line against those exposed in the 2000-01 Shepherdson Inquiry as vote-rorters inside his own Labor Party. He also denounced economic rationalism and National Competition Policy, and pledged instead a 'social rationalism' that allegedly valued communities above profits. Beattie's pragmatism was also found in his happy acceptance of opposition criticism of him as a 'media tart': censure doled out for his ubiquitous media presence, and for his release of policy at frequent press conferences with a silent minister by his side. While media stunts, such as the infamous swimming with sharks and kissing of piglets, were decried as meaningless distractions, they also proved endearing - at least initially - to an electorate jaded by overly sober politicians. Beattie also tactically exploited opposition disarray in the 2001 election when he urged Queenslanders - under the state's optional preferential voting system - to 'Just Vote One'. A landslide 66 seats in an 89-seat chamber was the result. But Beattie's pragmatism also saw him engage with former opponents, including Bjelke-Petersen, and consult with a wide variety of pressure groups in order to lock stakeholders in to subsequent policy. It was a strategy that earned Beattie a 
reputation as an 'inclusive populist'. ${ }^{6}$ But perhaps Beattie's ultimate pragmatic expression is found in the mea culpas that saw him regularly concede failed policy, humbly apologise and 'backflip' to a more electorally acceptable position. The reversal of such unpopular proposals as removing the state's petrol subsidy, and the collection of an ambulance levy via council rates notices, are cases in point. ${ }^{69}$ This populist approach, best described as 'metapopulism', ${ }^{70}$ became Beattie's own invention. It can be defined as a style of political leadership that blends traditional populist elements with modern traits of inclusion and flexibility to create, through the media lens, an 'everyman' image of which followers are both accepting and aware. Metapopulism can therefore mix idealism with pragmatism, pluralism with authoritarianism, and the social progressive with the conservative. In providing leaders with the flexibility to identify with 'battlers' and business in equal measure, it is the ultimate expression of 'vote-catching'.

\section{Regionalism}

So critical has the economic political and cultural influence of Queensland's regional and rural areas been over 150 years that no administration can hope to govern for, or from, the state's south-east alone. Any government ignoring the 'country-mindedness' of regional pressures - in either rhetoric or practice would be condemned to electoral oblivion. Indeed, most premiers and ministers since 1859 have ardently defended decentralisation and, moreover, have proudly represented electorates outside Brisbane. The first real testing of regional muscle came in the 1860s when Macalister fought to make Ipswich the state's capital. Importantly, nineteenth century transport did not prevent premiers from touring the state widely and regularly. McIlwraith, for example, sailed in 1882 from Brisbane to Cooktown, while Griffith also serviced the regions to electoral advantage. And, despite his tragically short tenure, Thomas Byrnes (1898) - who died in office at age 37 after just five months - obliged regional Queensland's rural demands for Kanak labour. ${ }^{71}$

Regionalism became institutionalised from the time when Robert Philp, a member of the Townsville Separation League, entertained ideas of a separate state of North Queensland. It was a sentiment shared by William Kidston who - in regarding himself as 'a Rockhampton man first and a Labor man second' similarly argued for a separate state for Central Queensland. ${ }^{72}$ Given that Labor's early electoral strength lay in Queensland's regional working class, it is perhaps unsurprising that Ryan, in representing Barcoo, should also champion the bush. Indeed, Ryan's empathy with struggling sugar farmers won over previous liberal constituencies. ${ }^{73}$ Theodore, too, represented a rural seat (Chillagoe) and toured the state widely, as did Forgan Smith (Mackay), who never lost his regional identity. It is even more noteworthy that Hanlon, the 'city bushman' representing Ithaca in Brisbane, remained one of the 'staunchest advocates of ruralistic economic policies' in his bid to curb Brisbane's growth. ${ }^{74}$ Indeed, his 1949 zonal malapportionment weighted rural electorates over urban. 
If ruralism received succour under Labor, it enjoyed manna on the return in 1957 of a Country Party-led Coalition. Nicklin, and in turn Bjelke-Petersen, demonstrated extreme regional bias in the form of heavy and generous state support for primary industries, and in the tightening of the zonal electoral system to further benefit rural voters now firmly ensconced within the Country Party camp. Indeed, Bjelke-Petersen traversed Queensland more than any predecessor, later assisted by a government jet. Even leaders of the immediate post-Joh era - Mike Ahern and Russell Cooper - represented seats outside Brisbane, the last premiers to do so. But Goss could be decidedly blasé about regional affairs, a fact which contributed to his 1996 downfall after several years of harsh economic rationalism that saw critical regional infrastructure close. Borbidge, a Gold Coast businessman, found it equally difficult to connect with regional voters, despite some loud 'tub-thumping' over gun control and Wik.

But populist regional sensitivities soon resumed under Beattie, who made much of his humble Atherton upbringing. Thus Beattie - ever aware of the anti-Goss backlash and subsequent surge in regional support for Pauline Hanson's One Nation - toured the regions extensively (often wearing an Akubra hat) to ensure that rural concerns were met. Beattie also undertook statewide pre-election 'listening tours', established a Community Engagement Division and - perhaps most significantly pioneered the Community Cabinet program that saw the ministry meet in, and consult with, communities across the state. Regional parliamentary sittings in Townsville and Rockhampton - the first ever outside George Street - were also well received. Beattie also pump-primed regional economies by regularly committing more than half the state's capital works budgets to projects outside Brisbane, ${ }^{75}$ criticised the omission of sugar farmers from the United States-Australia Free Trade Agreement and - in placating the far west and north - ignored South-East Queenslanders' pleas for the introduction of daylight saving. Bligh, too, has paid at least partial regard to the regions in, for example, the 2025 Far North Queensland Regional Plan, and in subsidising Rockhampton's Queensland Resources Exposition.

\section{State Development}

The mantra of state development has been the natural corollary to the politics of regionalism - one that cultivated a 'frontier' mentality, a strong sense of government paternalism and, all too often, 'progress' at all costs in the exploitation of the tabula rasa. While development and the quest to tame an unkind land were, of course, evident under New South Wales' jurisdiction from $1824,{ }^{76}$ after Separation the politics of development emerged at centre stage.

Land Acts, known as 'Herbert's Code', were passed in the early 1860s to encourage rapid settlement. The utilitarian view was that largesse that was extended to one region must necessarily benefit the entire colony. This logic also saw the government play a role in determining what crops should be grown, and where. Macalister shared Herbert's zeal for expansion when, despite dire warnings, he borrowed heavily for colonial infrastructure. It was perhaps the foresight of 
Macalister - the 'father' of the Queensland rail system - that laid the foundations for the colony's later economic success. Rail and land received further fillips under McIlwraith, as did a nascent mining industry under the Goldfields Act $1874 .{ }^{77}$ Political expediency meant that the liberal Griffith could only agree with McIlwraith's expansionist vision, but with the caveat of a more moderate rate of growth to allow small landholders a market share, and for the state to control mining. It would be a view shared by Philp who would later subsidise the sinking of 'deep' mines. Economic woes later saw Kidston trumpet the need for the state to absorb unemployment with development projects, a goal close to Forgan Smith's own heart in his 'permanent' capital works program that resulted in, among other things, the Story Bridge and the Somerset Dam. ${ }^{78}$

The accession in 1957 of a Coalition that rhetorically disavowed centralism and socialism, and instead championed free and private enterprise, did nothing to slow the pace of Queensland government intervention in the economy. Indeed, premiers from Nicklin to Bjelke-Petersen, in their support for regulation and primary industry marketing boards, clearly practised 'agrarian socialism'. Nicklin, for example, proudly claimed that, during his tenure, road mileage, agricultural output and secondary schools doubled in number, while irrigation, government buildings and mining trebled. ${ }^{79}$ It would be a pitch Bjelke-Petersen himself would make years later in his own election advertisements where Queensland's 'progress' would be trumpeted in raw statistics akin to the planned economy of a Soviet-era Eastern European state. Bjelke-Petersen, moreover, made incessant references to 'cranes on the horizon' as an indicator of economic well-being, an allusion Peter Beattie would also later use. Indeed, Beattie's championship of development especially outside Brisbane - saw him recite 'jobs, jobs, jobs' and the 'Smart State' as economic mantras, and laud the luring of Virgin Airlines' headquarters to Brisbane as an economic coup. Beattie's later multi-billion dollar South-East Queensland Regional Plan - Australia's largest capital works program - also found pride of place, as did such smaller developments as Roma Street and Lang Park. In true populist form, Beattie - usually under a construction hard hat - pledged to make Queensland the 'California of the Pacific'. Bligh, then, faced little option but to pursue economic development, and has placed enormous political stock in completing the long-vaunted South-East Queensland Water Grid. Bligh, moreover, happily accepted the capacity of the state to 'heal' economic woes when, in January 2009, she appointed a sixteen-member 'jobs squad' of leading business figures to advise on the mitigation of the impact of the global financial crisis on Queensland. ${ }^{80}$

\section{Queensland Chauvinism}

The fifth element of the state's political culture - a deep reverence for all things Queensland - has perhaps represented the most cleverly manipulated theme in Queensland politics. Successive Queensland premiers sought to exploit Queenslanders' sense of not only being different from, but superior to, their fellow Australians. In appealing positively to Queenslanders' patriotism, and 
negatively to their petty jealousies, Queensland chauvinism played on notions of 'country-mindedness', isolation and high virtue in the uniting of the state behind the premier against all outside 'threats' - including dreaded 'southerners'. There is little doubt that, while such sentiments emerged before 1859 in what was then a far-flung corner of New South Wales, separation only underscored a sense of difference and entitlement. McIlwraith, for example, capitalised on colonial pride when he annexed eastern New Guinea in 1883, and thereafter campaigned on Queensland sentimentality during the 1888 election that 'reinforced that alliance between nativism and populism' ${ }^{81}$

But Queensland chauvinism was more evident under Philp who, as a 'tenacious guardian of Queensland's interests', exploited fears that federalism would 'infect Queensland with radical influences'. ${ }^{82}$ This became evident in Queensland's lack of enthusiasm - even suspicion - for Federation. In the 1899 referendum, for example, Queensland returned the narrowest 'yes' vote of any colony, with Brisbane returning the highest 'no' vote of any capital city. Had just 4,000 more Queenslanders voted 'no', the colony would not have joined the new Australia. ${ }^{83}$ While always near the surface, states' rights burst through under Labor's Forgan Smith during the High Court's 1942 Uniform Taxation case, which centralised income taxation under Commonwealth jurisdiction. The fact that Labor also occupied the Treasury benches in Canberra mattered little. Bjelke-Petersen, too, capitalised upon anti-Canberra sentiment under Coalition and Labor federal governments alike, although Bjelke-Petersen reserved a special mistrust for reformist Prime Minister Gough Whitlam. Not only did Bjelke-Petersen regularly campaign against a 'socialist' federal government robbing Queensland of its rightful entitlements, he also legislated to enshrine Elizabeth II as the 'Queen of Queensland' to thwart any national republicanism.

Logic suggests that state chauvinism should have dissipated over time as a sense of 'Australianness' developed. But Beattie, too, exploited Queensland parochialism with an alacrity approximating Bjelke-Petersen's. Not only did Beattie annually lash Canberra (as all state premiers do) over inadequate GST shares, he also regularly engaged in unabashed patriotism, even declaring Queensland 'the most desirable state to visit in the world'. ${ }^{84}$ Indeed, Beattie, in conceding he was born in Sydney, cheekily added he 'had the good judgement to leave'. ${ }^{85}$ Beattie also talked up the superiority of Queensland's products, from table wines to taxi drivers. And, like the expansionist McIlwraith, Beattie also suggested that the northern New South Wales town of Lismore join Queensland. But it was undoubtedly during the annual Rugby League 'State of Origin' clashes that Beattie most profoundly exploited Queensland parochialism, ensuring that the Queensland flag flew over the Sydney Harbour Bridge when the 'cane toads' defeated the New South Wales 'cockroaches'. And, while Bligh appears less forthright in her appeal to state chauvinism, she premier at least dabbles in the parochialism of Queensland sport. ${ }^{86}$ 


\section{Conclusion}

Queensland has long been described as 'different' in its geography, its industry, its decentralised population and, most notably, its politics and public attitudes. That these elements should intersect is no accident: it has long been argued that Queensland's distinctive political culture - its way of thinking about politics - is a direct function of the state's physical, economic and demographical characteristics. This article has explored how the Queensland premiership developed over 150 years in response to those factors that have shaped a unique Queensland political culture routinely described as 'populist'. The article argued three theses: that the characteristics comprising the successful Queensland premiership did not begin in recent times but can be traced at least to Queensland's separation from New South Wales in 1959, and even to the time of the Moreton Bay settlement in 1824; that most premiers have exploited Queensland's political culture for electoral expedience, with varying degrees of success and with some elements of that pattern of behaviour still present today; and that certain events - from economic depression to media innovations to changes in political institutions - have only served to enhance the power and authority of Queensland premiers.

Two further conclusions can also be drawn. First, successive Queensland premiers have not only been shaped by the dominant political culture but have also, in turn, shaped that political culture by serving as models for subsequent leaders eager to maintain power. It is clear, for example, that Lilley learnt from Herbert, while McIlwraith and Griffith borrowed from each other. In turn, McCormack and Forgan Smith learnt from Theodore, while Nicklin and Bjelke-Petersen modelled aspects of their leadership on Hanlon and Gair. Second, it can be concluded that, despite an ongoing 'Australianisation' of the national culture, elements of Queensland's unique political culture remain in practice today. Indeed, Peter Beattie - heeding the lessons of leaders as different as Joh Bjelke-Petersen and Wayne Goss - crafted 'metapopulism' as an electoral tool: his own enormously successful adaptation of Queensland populism and political culture that delivered him three successive electoral landslides. The electoral salience of Queensland's traditional political culture will undoubtedly diminish over time as the state becomes increasingly homogenised with the rest of Australia. But, in the short- to mid-term, the populism of strong leadership, pragmatism, regionalism, state development and state chauvinism will continue to serve Queensland premiers well.

\section{Notes}

1 For a discussion of these theories, see E.H. Carr, What is History? (Middlesex: Penguin, 1977); and T. Bottomore, Political Sociology (London: Hutchison, 1979).

2 See, for example, P. Charlton, State of Mind: Why Queensland is Different (Sydney: MethuenHaynes, 1983); H. McQueen, 'States of the Nation - Queensland: A State of Mind', Meanjin 38 (1979): 41-51; D. Murphy, 'Queensland's Image and Australian Nationalism', Australian Quarterly 50 (1978): 77-91. 
3 See, for example, E. Reid, 'Queensland', in Max Harris and Geoffrey Dutton, eds, Sir Henry, Bjelke, Don Baby and Friends (Melbourne: Sun Books, 1971).

4 C. Hughes, 'Political Culture', in H. Mayer and H. Nelson, eds, Australian Politics: A Third Reader (Melbourne: Cheshire, 1973), 133.

5 C. Hughes, 'Political Culture'; H. McQueen, 'States of the Nation'.

6 See R. Evans. A History of Queensland (Melbourne: Cambridge University Press, 2007), 43-44.

7 For this and the following discussion, see R. Fitzgerald, A History of Queensland: From the Dreaming to 1915 (St Lucia: University of Queensland Press, 1982); P. Smith, 'Queensland's Political Culture', in A. Patience, ed., The Bjelke-Petersen Premiership, 1968-1983: Issues in Public Policy (Melbourne: Longman Cheshire, 1985); H. McQueen, 'States of the Nation'; and P. Williams, 'State of Attitude', The Weekend Australian, 13 August 2005.

8 See, for example, D. Aitkin, The Country Party in New South Wales (Canberra: ANU Press, 1972).

9 D. Waterson, 'Thomas McIlwraith: A Colonial Entrepreneur', in D. Murphy, R. Joyce and M. Cribb, eds, The Premiers of Queensland, 2nd ed (St Lucia: University of Queensland Press, 1990), 139.

10 See, for example, J. Walter and K. Dickie, 'Johannes Bjelke-Petersen: A Political Profile', in Patience, The Bjelke-Petersen Premiership, 43; Waterson, 'Thomas McIlwraith', 121; P. Adams, 'Pauline and Prejudice: It's in the Bag', in Two Nations: The Causes and Effects of the Rise of the One Nation Party in Australia (Melbourne: Bookman Press, 1998), 21; G. Stokes, 'One Nation and Australian Populism', in M. Leach, G. Stokes and I. Ward, eds, The Rise and Fall of One Nation (St Lucia: University of Queensland Press, 2000), 25.

11 See, for example, M. Canovan, Populism (New York: Harcourt Brace Jovanovich, 1981); R. Wear, 'The Permanent Populism of the Howard Government, 1996-2007', The Australian Journal of Political Science 43.4 (2009): 617-34.

12 Canovan, Populism, 3-16.

13 D. Jaensch and M. Teichmann, eds, The Macmillan Dictionary of Australian Politics, 2nd ed. (Melbourne: Macmillan, 1979), 157.

14 C. Hughes, The Government of Queensland (St Lucia: University of Queensland Press, 1980), 13, 154-55.

15 R. Joyce, 'George Ferguson Bowen and Robert George Wyndham Herbert: The Imported Openers', in Murphy, Joyce and Cribb, The Premiers of Queensland, 11-12.

16 H. Gibbney, 'Charles Lilley: An Uncertain Democrat', in Murphy, Joyce and Cribb, The Premiers of Queensland, 71.

17 C. Bernays, Queensland Politics During Sixty Years: 1859-1919 (Brisbane: Government Printer, 1919), 39.

18 Bernays, Queensland Politics, 56, 85.

19 Waterson, 'Thomas McIlwraith', 119, 128.

20 R. Joyce, 'Samuel Walker Griffith: A Liberal Lawyer', in Murphy, Joyce and Cribb, The Premiers of Queensland, 140, 166-68.

21 See D. Murphy and R. Joyce, 'Introduction to the 1978 Edition', in Murphy, Joyce and Cribb, The Premiers of Queensland, 3.

22 D. Murphy, 'William Kidston: A Tenacious Reformer', in Murphy, Joyce and Cribb, The Premiers of Queensland, 224.

23 C. Bernays, Queensland Politics, 152.

24 D. Murphy, 'Thomas Joseph Ryan: Big and Broadminded', in Murphy, Joyce and Cribb, The Premiers of Queensland, 263, 275.

25 D. Murphy, 'Edward Granville Theodore: Ideal and Reality', in Murphy, Joyce and Cribb, The Premiers of Queensland, 293, 316-17.

26 See R. Evans, The Red Flag Riots: A Study of Intolerance (St Lucia: University of Queensland Press, 1988). 
27 K. Kennedy, 'William McCormack: Forgotten Labor Leader', in Murphy, Joyce and Cribb, The Premiers of Queensland, 362, 369; R. Fitzgerald and H. Thornton, Labor in Queensland: From the 1880s to 1988 (St Lucia: University of Queensland Press, 1989), 82.

28 R. Fitzgerald, A History of Queensland: From 1915 to the Early 1980s (St Lucia: University of Queensland Press, 1984), 100.

29 See 'A History of Local Radio in Brisbane', in ABC Brisbane, www.abc.net.au/local/ stories/2008/02/18/2165437.htm (accessed 30 January 2009).

30 R. Fitzgerald, A History of Queensland, 101; B. Carroll, 'William Forgan Smith: Dictator or Democrat?' in Murphy, Joyce and Cribb, The Premiers of Queensland, 408-27.

31 K. Knight, 'Ned Hanlon: A City Bushman', in Murphy, Joyce and Cribb, The Premiers of Queensland, 433.

32 B. Costar, 'Vincent Clair Gair: Labor's Loser', in Murphy, Joyce and Cribb, The Premiers of Queensland, 459.

33 Costar, 'Vincent Clair Gair', 468.

34 Fitzgerald and Thornton, Labor in Queensland, 146, 154.

35 B. Stevenson, "George Frank Reuben Nicklin: "Honest Frank" - the Gentleman Premier", in Murphy, Joyce and Cribb, The Premiers of Queensland, 488.

36 Stevenson, 'George Frank Reuben Nicklin', 486.

37 See The History of Australian Television, 'The Sixties', www.televisionau.com/sixties.htm (accessed 30 January 2009).

38 P.D. Williams, 'Pizzey, Jack Charles Allen (1911-1968)', Australian Dictionary of Biography, Vol. 16 (Melbourne: Melbourne University Press, 2002), 9-10.

39 See, for example, H. Lunn, Johannes Bjelke-Petersen: A Political Biography (St Lucia: University of Queensland Press, 1984); D. Wells, The Deep North (Melbourne: Outback Press, 1979); R. Wear, Johannes Bjelke-Petersen: The Lord's Premier (St Lucia: University of Queensland Press, 2002); and Patience, The Bjelke-Petersen Premiership.

40 J. Walter, 'Johannes Bjelke-Petersen: The Populist Autocrat', in Murphy, Joyce and Cribb, The Premiers of Queensland, 499.

41 Wear, Johannes Bjelke-Petersen, 139.

42 See P.D. Williams, 'The Queensland Election of 7 February 2004: The Coming of the Second Labor Hegemony?' The Australian Journal of Political Science, 39.3 (2004): 635-44.

43 R. Wear, 'Wayne Goss - a Leader in the Queensland Tradition?' in B. Stevens and J. Wanna, eds, The Goss Government: Promise and Performance of Labor in Queensland (Melbourne: Macmillan, 1993).

44 J. Wanna, 'Wayne Keith Goss: The Rise and Fall of a Meticulous Controller', in D. Murphy, R. Joyce, M. Cribb and R. Wear, eds, The Premiers of Queensland, 3rd ed. (St Lucia: University of Queensland Press, 2003), 359.

45 Wanna, 'Wayne Keith Goss', 369.

46 P.D. Williams, 'No More Mr Nice Guy', Courier-Mail, 25 August: 29.

47 P. Beattie, Making a Difference: Reflections on Life, Leadership and Politics (Sydney: Harper Collins, 2005).

48 See, for example, 'Opportunity for Renewal Squandered', Courier-Mail, 26 September 2006.

49 See S. Parnell and S. Elks, 'Conservatives Clinging to Poll Position', The Australian, 20 March 2009.

50 Female Chief Ministers of Australia's territories have boasted previous success. The Australian Capital Territory's Rosemary Follett (Labor) became chief minister after the 1989 and 1992 ACT elections, with Kate Carnell (Liberal) being similarly appointed after the 1995 and 1998 ACT polls. The Northern Territory's Clare Martin (Labor) was elected Chief Minister after the 2001 and 2005 Territory elections.

51 Wear, 'Wayne Goss', 25.

52 Evans, A History of Queensland, 79. 
53 Joyce, 'George Ferguson Bowen and Robert George Wyndham Herbert', 20.

54 P. Wilson, 'Arthur Macalister: "Slippery Mac", in Murphy, Joyce and Cribb, The Premiers of Queensland, 45.

55 Bernays, Queensland Politics During Sixty Years, 90-91.

56 See P. Reynolds, 'Connectional Politics: The Queensland Case', paper presented to the Australasian Political Studies Association Conference, Griffith University, Brisbane, 1991.

57 Bernays, Queensland Politics During Sixty Years, 136.

58 Murphy, 'William Kidston', 255.

59 W.R. Johnston and D. Murphy, 'Ryan, Thomas Joseph (Tom) (1876-1921)', Australian Dictionary of Biography, Vol. 11, 496-500.

60 I. Young. Theodore: His Life and Times (Sydney: Alpha Books, 1971), 33; see also Murphy, 'Edward Granville Theodore', 300.

61 Queensland's electoral system between 1949 and 1992 is often erroneously described as a 'gerrymander' (or the irregular and illogical drawing of boundaries). Queensland's imbalanced weighting of electorates in favour of rural constituencies is more accurately described as 'malapportionment'.

62 Stevenson, 'George Frank Reuben Nicklin', 489; Fitzgerald, A History of Queensland, 242.

63 Fitzgerald and Thornton, Labor in Queensland, 182.

64 Wear, Johannes Bjelke-Petersen, 94.

65 R. Wear, 'Robert Edward Borbidge: In the Shadow of Bjelke-Petersen', in D. Murphy, R. Joyce, M. Cribb and R. Wear, eds, The Premiers of Queensland, 3rd ed. (St Lucia: University of Queensland Press, 2003), 393.

66 R. Wear, 'One Nation and the Queensland Right', in Leach, Stokes and Ward, The Rise and Fall of One Nation, 68.

67 See J. Wanna and P.D. Williams, 'Peter Beattie: The "Boy from Atherton" Made Good', in J. Wanna and P.D. Williams, eds, Yes, Premier: Labor Leadership in Australia's States and Territories (Sydney: UNSW Press, 2005).

68 N. Preston, 'Peter Douglas Beattie: The Inclusive Populist', in Murphy, Joyce, Cribb and Wear, The Premiers of Queensland.

69 P.D. Williams. 'Peter Beattie's Strategies of Crisis Management: Mea Culpa and the Policy "Backflip"', The Australian Journal of Public Administration 64.4 (2005): 41-52.

70 P.D. Williams, 'Metapopulism: Peter Beattie and the Reinvention of Queensland Populist Discourse', paper delivered to the Australasian Political Studies Association Conference, Griffith University, Brisbane, September 2001.

71 R. Gill, 'Thomas Joseph Byrnes: The Man and the Legend', in Murphy, Joyce and Cribb, The Premiers of Queensland, 184.

72 Murphy, 'William Kidston', 228.

73 D. Murphy, T J Ryan: A Political Biography (St Lucia: University of Queensland Press, 1990), 254-55.

74 Knight, 'Ned Hanlon', 445.

75 See, for example, S. Connolly, 'Hamill Delivers a One-Day Wonder', AAP, 18 July 2000; S. Balogh, 'HIH Drags Beattie's Books into the Red', The Australian, 20 June 2001.

76 See Evans, A History of Queensland, 25-77.

77 Bernays, Queensland Politics, 359.

78 Carroll, 'William Forgan Smith', 400.

79 Stevenson, 'George Frank Reuben Nicklin', 492.

80 See 'Bligh Starts Job Squad', The Australian, 26 January 2009.

81 Waterson, 'Thomas McIlwraith', 119-21.

82 G. Bolton, 'Robert Philp: Capitalist as Politician', in Murphy, Joyce and Cribb, The Premiers of Queensland, 208. 
83 Evans. A History of Queensland, 141; see also G. Blainey, A Shorter History of Australia (Melbourne: William Heinemann, 1994), 133.

84 See Courier-Mail, 10 May 2000; 9 June 2000; 6 August 2000.

85 PM, ABC Radio, Transcript, 'Queensland Flag Flies on Sydney Harbour Bridge', interview with David Spicer, 28 June 1999, www.abc.net.au/pm/stories/s31915.htm (accessed 1 February 2009).

86 See 'Premiers Agree to Disagree - but Charity an Origin Winner', media release, 21 May 2008, www.cabinet.qld.gov.au/MMS/StatementDisplaySingle.aspx?id=58139 (accessed 1 February 2009). 